\title{
El paisatge lingüístic del centre històric de València: sobre la presència del català
}

\section{The linguistic landscape of the historic centre of Valencia: on the presence of Catalan}

\author{
Lidia Latorre García \\ Andrea García Montes \\ Universitat de València \\ lilagar@alumni.uv.es \\ angarmo4@alumni.uv.es
}

Data de recepció: 30/04/2018

Data d'aceptació: 03/07/2018

\section{Resum}

El paisatge lingüístic (PL) és una disciplina lingüística que s'ha desenrotllat tant en l'àmbit internacional com en l'hispànic en els últims anys. El seu objecte d'estudi és «the visibility and salience of languages on public and comercial signs in a given territory or region» (Landry i Bourhis, 1997: 23).

En aquesta investigació hem volgut aplicar la base teòrica del PL per a comprovar la realitat lingüística dels signes presents al centre històric de la ciutat de València. Sobretot ens interessa observar la presència (o absència) del català en aquests signes, comprovar com es relacionen els resultats amb les disposicions legislatives en matèria de política lingüística i observar la rellevància que es dóna al català en els signes bilingües i multilingües.

Amb aquests objectius, vam analitzar 368 signes i els hem classificat en: institucionals o privats, d'una banda, i segons el nombre de llengües en què estaven escrits, de l'altra. Aquesta anàlisi ens permetrà arribar a la conclusió que la llengua que predomina en els signes privats és el castellà, mentre que el català predomina als institucionals.

Paraules clau: paisatge lingüístic; prestigi lingüístic; català; política; lingüística; signe.

\begin{abstract}
The linguistic landscape (LP) is a linguistic discipline developed recently in the international and Hispanic fields. Its subject matter is «the visibility and salience of languages on public and commercial signs in a given territory or region» (Landry and Bourhis, 1997: 23).

This investigation wanted to use the theoretical bases of LP to verify the linguistic reality of the signs in the historic centre of Valencia. The main objective of this paper is to study the presence (or absence) of Catalan in these signs, checking how the results are related to the laws of language policy and the relevance of Catalan in bilingual and multilingual signs.

To achieve these objectives, 368 signs had been analysed and classified in: institutional or private and depending on the number of languages they contained. This analysis concludes that the prevailing language in private signs is Spanish whereas the Catalan predominates in the institutional signs.
\end{abstract}

Keywords: linguistic landscape; linguistic prestige; Catalan; language policy; sign.

Latorre García, Lidia i García Montes, Andrea (2020). "El paisatge lingüístic del centre històric de València: sobre la presència del català". Revista Estudis Filològics $i$ de Traducció (EFIT) 1: 187-206. Doi: 10.7203/ efit. 1.16438 
$-188-$

$88-$ 


\section{Taula de continguts}

1. Introducció

1.1. Objectius

1.2. Context normatiu

1.3. Context social

1.4. Hipòtesi de partida

2. Metodologia

2.1. Classificació dels signes

2.2. Obtenció del corpus

3. Anàlisi

3.1. Anàlisi quantitativa

3.2. Anàlisi qualitativa

3.2.1. Compliment de la normativa lingüística autonòmica i municipal

3.2.2. Prestigi del català

3.2.3. Valor simbòlic dels signes en català

4. Conclusions

Bibliografia 



\section{Introducció}

La base teòrica del nostre estudi és el paisatge lingüístic (PL). Aquest àmbit d'estudi lingüístic és definit per Landry i Bourhis (1997:25) com:

The language of public road signs, advertising billboards, street names, place names, commercial shops signs, and public signs on government building combines to form the linguistic landscape of a given territory, region or urban agglomeration. The linguistic landscape of a territory can serve two basic functions: an informational function and a symbolic function.

És a dir, aquesta nova teoria estudia el llenguatge dels signes que apareixen a l'espai públic d'un territori o una zona determinada. Aquests signes ${ }^{1}$ poden ser classificats seguint diferents criteris. El que seguirem en aquest treball és 1'exposat per Ben-Rafael, Shohamy, Amara i Trumper-Hecht (2006), que diferencien els signes institucionals (aquells que sorgeixen del govern i d'altres institucions cap al poble) i privats (aquells que sorgeixen directament des del poble).

El PL ha sigut especialment utilitzat per a estudiar zones bilingües i multilingües, on hi ha conflictes lingüístics com ara al País Basc o Canadà. En este sentit ha resultat una eina molt reveladora. És per això que hem volgut estudiar el PL del centre històric de la ciutat de València, on interactuen les polítiques lingüístiques, el bilingüisme de la ciutat i el plurilingüisme del turisme present a aquesta zona.

\subsection{Objectius}

Els objectius per als quals es va dissenyar aquesta investigació són els següents:

- Comprovar la presència del català en el centre històric, una de les zones més turístiques de València

- Comprovar l'impacte de les polítiques lingüístiques dutes a terme fins al moment

- Comprovar l'existència d'espais públics monolingües, bilingües i multilingües

1 En aquest treball s'utilitza signe amb el significat de 'rètol o cartell'. 


\subsection{Context normatiu}

La realitat de la ciutat de València és molt concreta perquè es tracta d'una ciutat oficialment bilingüe, amb una de les dues llengües, el català (denominat valencià en les diferents normatives), en situació de diglòssia. És per això, que les institucions públiques desenrotllen les tasques de protecció, cura i difusió de la llengua catalana. Amb aquests objectius existeix el Reglament Municipal sobre ús i normalització del valencià al municipi de València (2005), que, entre altres coses, conté els següents articles:

Article 12. 2.- L'Ajuntament informarà i assessorarà totes les entitats públiques $i$ privades, perquè col·laboren activament en la ràpida difusió de l'ús del valencià en les retolacions, anuncis, impresos de tota classe, $i$ en les comunicacions orals i escrites.

Article 16. 2.- Tots els noms de carrers, places, avingudes i, en general, qualsevulla denominació que servesca per a indicar un indret o espai determinat dins del territori municipal, així com la toponímia menor del terme municipal, tenen com a forma oficial la valenciana.

Article 17. 1.- Els rètols, cartells i indicacions existents en els immobles, dependències i serveis municipals hauran d'estar escrits en valencià.

2.- En les inscripcions o retolacions que identifiquen béns de propietat municipal, tant vehicles com immobles o utillatge en general, es procedirà de la mateixa manera.

3.- Els rètols de la via pública destinats a informar els transeünts, l'elaboració dels quals siga competència municipal, seran redactats preferentment en valencià.

Aquest reglament no només regula les llengües que apareixeran en els signes institucionals, sinó també influencien els signes privats, ja que afavoreixen la utilització del català a l'àmbit privat donant suport i informació als comerços i entitats que ho poden necessitar. 
A més, la legislació autonòmica estableix el català com la llengua que ha d'utilitzar-se en els rètols i en la toponímia ${ }^{2}$ de les zones amb predomini lingüístic valencià. Legislació que afecta a la ciutat de València perquè és considerada un territori on el català té un predomini lingüístic ${ }^{3}$, per tant, i tal com dicten els decrets del Consell de la Generalitat Valenciana 145/1986 i 61/2017 i l'ordre de l'1 de desembre de 1993, la llengua destacada d'ús normal i general és el català. I per aquest motiu, serà la llengua que haurà d'aparéixer en primera posició, i de forma destacada, als diferents signes lingüístics.

\subsection{Context social}

Respecte a la realitat social de la ciutat, pot entendre's des de dues perspectives. D'un costat, València tenia en 2016 amb 791632 habitants ${ }^{4}$, majoritàriament monolingües en castellà o bilingües en català i castellà. A més, integra minories immigrants, per això, podríem trobar signes en les llengües maternes d'aquests immigrants.

D’un altre costat, un dels motors principals de la ciutat és el turisme i la ciutat és un dels destins preferits del turisme nacional i internacional. En 2016, va rebre 931714 turistes espanyols i 976133 turistes estrangers 5 . Dades que ens marquen una situació clarament multilingüe i desigual ${ }^{6}$.

2 Respecte a la toponímia, s'han aprovat les següents disposicions normatives: el Nomenclàtor Oficial de Carrers (aprovat al gener de 2016) i el nom de València com a única denominació de la ciutat des de febrer de 2017.

3 Tal com s'indica en la relació de municipis de la Comunitat Valenciana que apareix en la següent pàgina web: http://www.ceice.gva.es/estatico/polin/WebHelp/Toponimia/municipis_de_la_comunitat_valenciana.html.

4 El nombre d'habitants de la ciutat de València es pot consultar en la pàgina web de l'Ajuntament de València: https://www.valencia.es/ayuntamiento/laciudad.nsf/vDocumentosTituloAux/poblacion\%20contenido?opendocument\&lang=1\&nivel=2_1. Tanmateix, les dades s'actualitzen anualment i no apareixen ja les de l'any 2016.

5 L'oficina de turisme de la ciutat de València ofereix en la seua pàgina web un informe amb les estadístiques dels visitants que va tindre la ciutat en $2016 \mathrm{i}$ es poden consultar en: https:/www.visitvalencia.com/sites/default/ files/estadisticas_turistas-2016.pdf.

6 Desigual perquè la necessitat de comunicar-se amb aquests turistes té com a conseqüència que els comerços utilitzen signes en llengües estrangeres, per tant està clar que el PL es veu alterar pels visitants. 


\subsection{Hipòtesi de partida}

Aquests contextos, normatiu i social, ens guien fins a una hipòtesi de partida. D'un costat, la llengua majoritària dels signes públics serà el català, encara que també hi haurà signes multilingües, dirigits especialment als turistes. De l'altre costat, les llengües principals en els signes privats seran el castellà i l'anglés, amb una aparició menor d'altres llengües.

\section{Metodologia}

Per tal de realitzar aquest estudi, primer, vam delimitar el nostre objecte d'anàlisi als signes observables a l'exterior: façanes, terrasses i cartes dels bars. Vam prendre la decisió d'incloure les cartes dels bars ${ }^{7}$, perquè encara que no hi eren tan visibles com els rètols dels establiments, també estaven a l'exterior del local i eren accessibles per a tothom.

Per últim, vam excloure de l'anàlisi tots aquells signes que no eren estàtics, com per exemple els fullets o els missatges en les samarretes dels vianants, de la mateixa manera que s'havia fet en altres estudis del PL, com el de Regueira, López Docampo i Wellings (2013).

\subsection{Classificació dels signes}

Una vegada obtingut el corpus amb aquestes limitacions, vam fer una classificació en dues fases: en primer lloc, vam diferenciar els signes institucionals (emesos pel govern espanyol, pel de la Comunitat Valenciana o per l'Ajuntament de València) dels signes privats (empreses i particulars). Aquesta distinció es veu motivada pels raonaments exposats per altres autors com Pons (2012: 66): «la naturaleza de esta distinción no solo se basa en el tipo de emisor, sino en que su respectiva contribución al paisaje lingüístico es muy disímil». Com hem vist en $\S 1.2$,

7 És en aquestes cartes de bar on trobem una gran varietat de signes multilingües, ja que apareixen en un mateix signe llengües com el rus, el japonès o l'alemany junt amb l'anglés o el castellà. 
els signes institucionals es regeixen per obligacions legals, mentre que els privats, poden tindre usos recomanats, però és l'individu qui decideix què escriure, com escriure-ho i en quina llengua.

En una segona fase, vam classificar els signes segons el nombre de llengües que incloïen: monolingües, bilingües, multilingües i ambigus ${ }^{8}$.

\subsection{Obtenció del corpus}

Per a obtenir el nostre corpus vam recórrer a peu els tretze carrers següents del centre històric de València: plaça de la Reina, plaça de la Mare de Déu, plaça de Santa Caterina, carrer de la Capelleria, plaça de Lope de Vega, plaça de la Mare de Déu de la Pau, carrer dels Brodadors, carrer del Micalet, carrer de la Batlia, passatge Emili M. Aparicio Olmos, plaça de l'Almoina, carrer de la Barcella i plaça de Dècim Juni Brut.

\section{Anàlisi}

\subsection{Anàlisi quantitativa}

El corpus fotogràfic obtingut, després de l'anàlisi dels tretze carrers citats anteriorment, conté un total de 368 signes.

Una primera classificació d'aquests signes, segons el seu emissor, ens permet distingir entre signes institucionals (65) i signes privats (300):

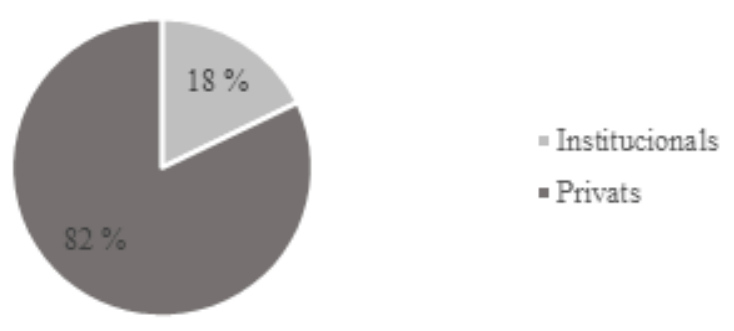

Figura 1. Signes segons l'emissor

8 Aquests signes ambigus són els que «no pertenecen a una lengua concreta [...] o se pueden adscribir a varias lenguas» (Pons, 2012: 76). Tractarem, en la manera possible, de desambiguar-los mitjançant els senyals amb els que conviu. 
Una vegada hem distingit els signes privats dels institucionals, ens interessa classificar aquests segons quantes llengües hi apareixen i quines són aquestes.

Per una part, els signes institucionals analitzats presenten la distribució següent:

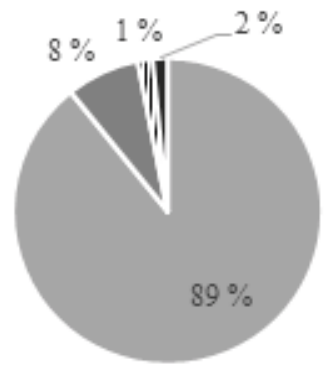

$$
\begin{aligned}
& \text { - Monolingüe } \\
& \text { - Bilingüe } \\
& \text { " Multilingüe } \\
& \text { - Ambigus }
\end{aligned}
$$

Figura 2. Signes institucionals per llengües

El castellà, el català i l'anglés són les llengües que apareixen en els signes institucionals analitzats com multilingües. A més, en els signes classificats com monolingües hem trobat dos sistemes diferents d'escriptura, ja que apareixen la majoria de signes escrits amb l'alfabet llatí, però hi ha un escrit en Braille. En general, l'ús del català i del castellà als signes institucionals monolingües presenta la següent distribució:
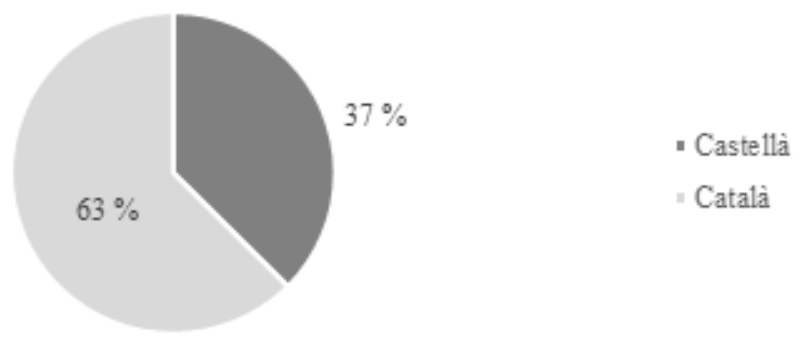

Figura 3. Llengües dels signes institucionals monolingües

Per altra part, els signes privats també els hem agrupat en monolingües, bilingües, multilingües i ambigus. El següent gràfic representa el percentatge d'aparició d'aquests tipus de signes: 


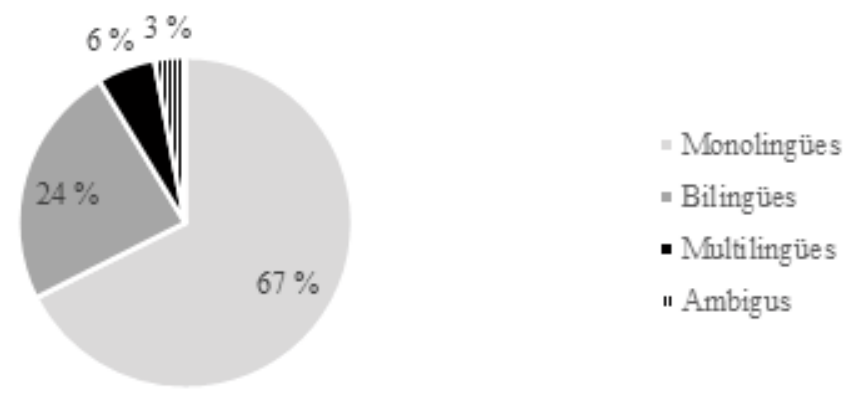

Figura 4. Signes privats per llengües

Dins dels monolingües hem trobat diferents llengües, com es pot observar en la següent figura:

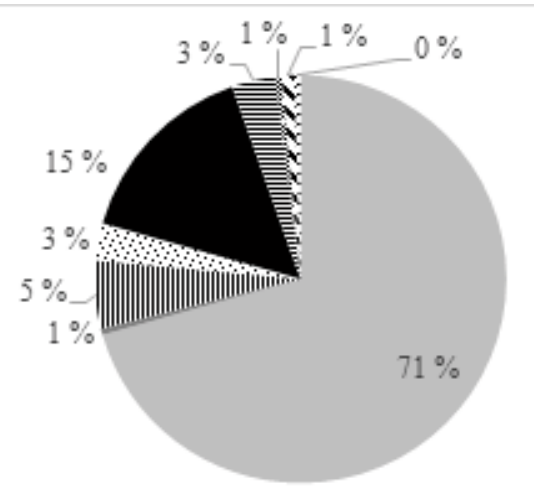

$$
\begin{aligned}
& \text { "Caste llà } \\
& \text { n Alemany } \\
& \text { II Català } \\
& \because \text { Francés } \\
& \text { - Anglés } \\
& \equiv \text { Italià } \\
& \text { « Japonés } \\
& \text {-Llati } \\
& \because \text { Rus }
\end{aligned}
$$

Figura 5. Llengües presents als signes monolingües privats

En el cas dels signes privats bilingües, hem vist dos tipus de combinació: la primera és l'aparició en un mateix signe del castellà amb alguna altra llengua i la segona consisteix en l'ús de l'anglés amb una altra llengua:

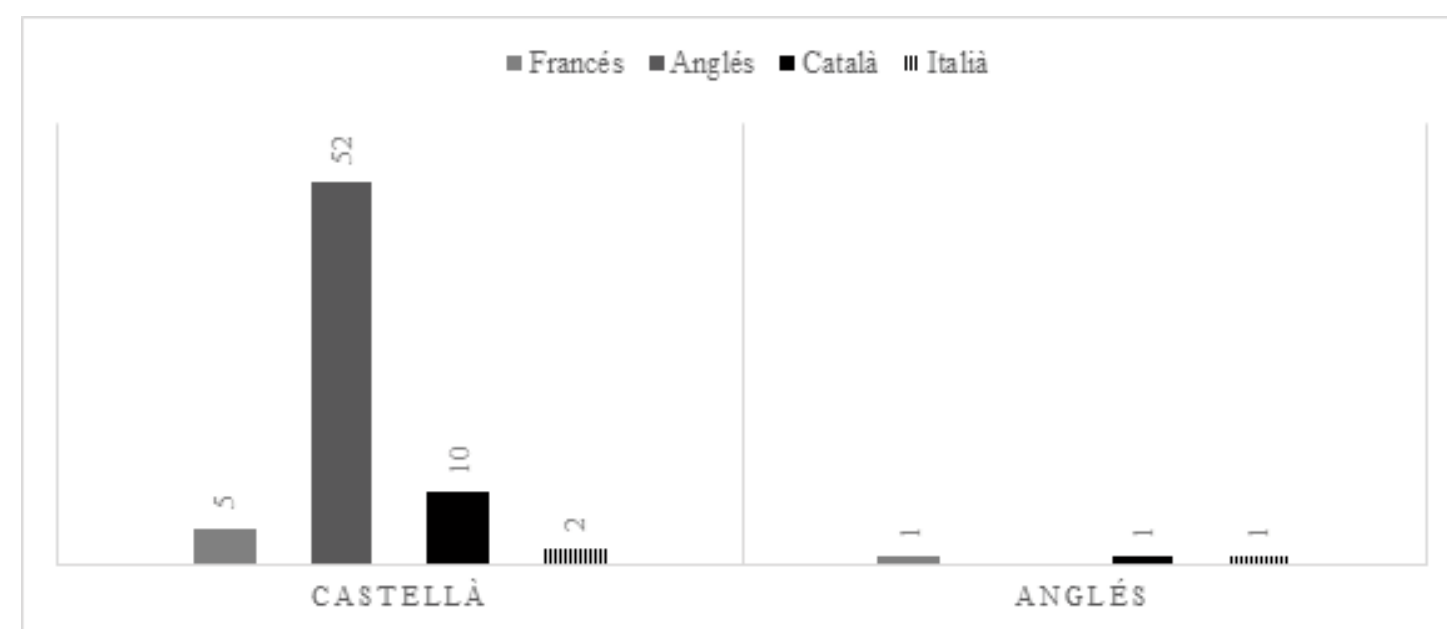

Figura 6. Combinació signes bilingües privats 
Per últim, quant als signes privats multilingües, hem trobat tres tipus de distribució: multilingües de tres llengües, de quatre i de set ${ }^{9}$.

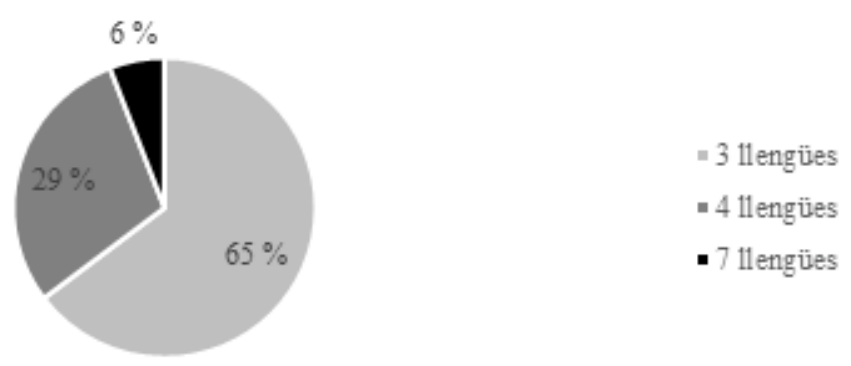

Figura 7. Nombre de llengües en els signes privats multilingües

\subsection{Anàlisi qualitativa}

\subsubsection{Compliment de la normativa lingüística autonòmica i municipal}

Un dels nostres objectius era comprovar si es complia la normativa lingüística autonòmica i municipal, per la qual els signes institucionals han d'aparéixer en català. Com hem vist en $\S$ 3.1., la majoria de signes institucionals són monolingües en català (60 \%), a més d'aparéixer en signes bilingües $(8 \%)$ i multilingües $(1 \%)$. Si sumem tots els percentatges d'aparició del català en els signes institucionals ens trobem amb un $69 \%$ de representativitat, és a dir, un $30 \%$ dels signes institucionals no utilitzen el català (com és el cas de la figura 8) i, per tant, no compleixen ni la normativa autonòmica ni la municipal que hem vist en $\S 1.2$.

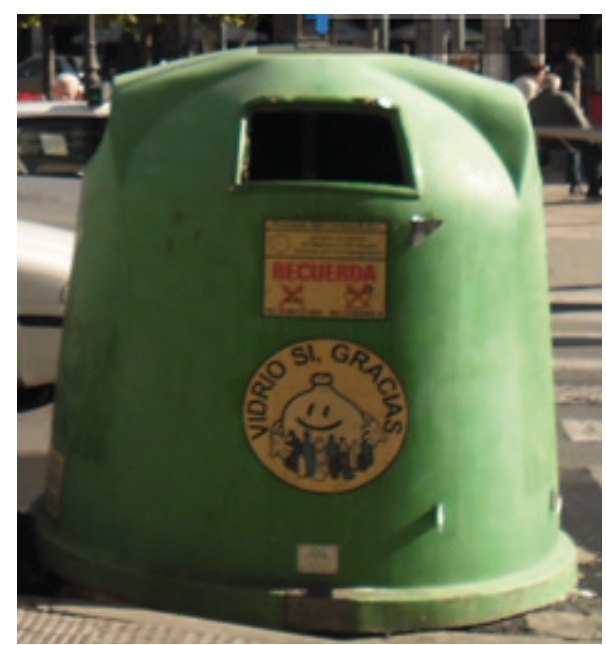

Figura 8. Signe institucional monolingüe castellà

$9 \quad$ La llengua que es troba sempre en aquests signes multilingües és el castellà en combinació amb l'anglés i una altra llengua. On apareixen signes amb set llengües és en les cartes de bar. 
També hem vist en $\S 1.2$. que l'Ajuntament de València recull en el seu reglament sobre l'ús del valencià la seua voluntat d'animar les entitats privades a utilitzar el català com a llengua d'ús i retolació. Tanmateix, aquest compliment és més irregular que en el cas dels rètols institucionals. És a dir, no és tan freqüent trobar-se en signes escrits en català, però hi ha (encara que són minoria), com es pot observar en la figura 9:

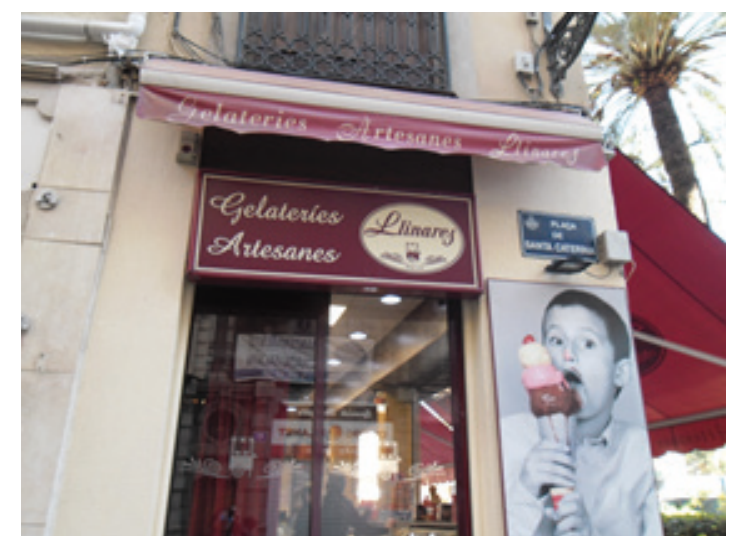

Figura 9. Signe privat en català

\subsubsection{Prestigi del català}

\section{Entenem per prestigi}

un comportamiento lingüístico motivado por las actitudes sociales adoptadas ante determinadas formas lingüísticas que se refieren a la estima que adquieren algunas variedades dialectales, acentos o incluso rasgos lingüísticos determinados, como consecuencia de una reputación adquirida o atribuida, que es totalmente subjetiva. (Hernández-Campoy, 2004: 41)

En la nostra investigació, hem estudiat el prestigi de la llengua pròpia de la Comunitat Valenciana (en signes bilingües i monolingües) a partir del concepte de jerarquia visual (Backhaus, 2007: 103; Regueira et al. 2013: 48). Com assenyalen, Regueira et al. (2013: 48) aquesta jerarquia es produeix inevitablement com a resultat de

la presencia de dos o más lenguas en un mismo espacio [...] ya que la lengua que se encuentra en una posición prominente (generalmente en la parte superior, con un tamaño o tipo de letra diferente) aparece como la original, mientras que las otras adoptan un estatus de simples traducciones. 
La posició prominent d'una llengua depén de l'orientació del signe, vertical o horitzontal. Backhaus (2007: 103) indica que «code preference is given to the version of a message positioned on top (in horizontal text) or on the right (in vertical text)».

Aleshores, si tenim en compte la posició del català, en el nostre cas, i la resta de llengües presents en el signe podem establir que:

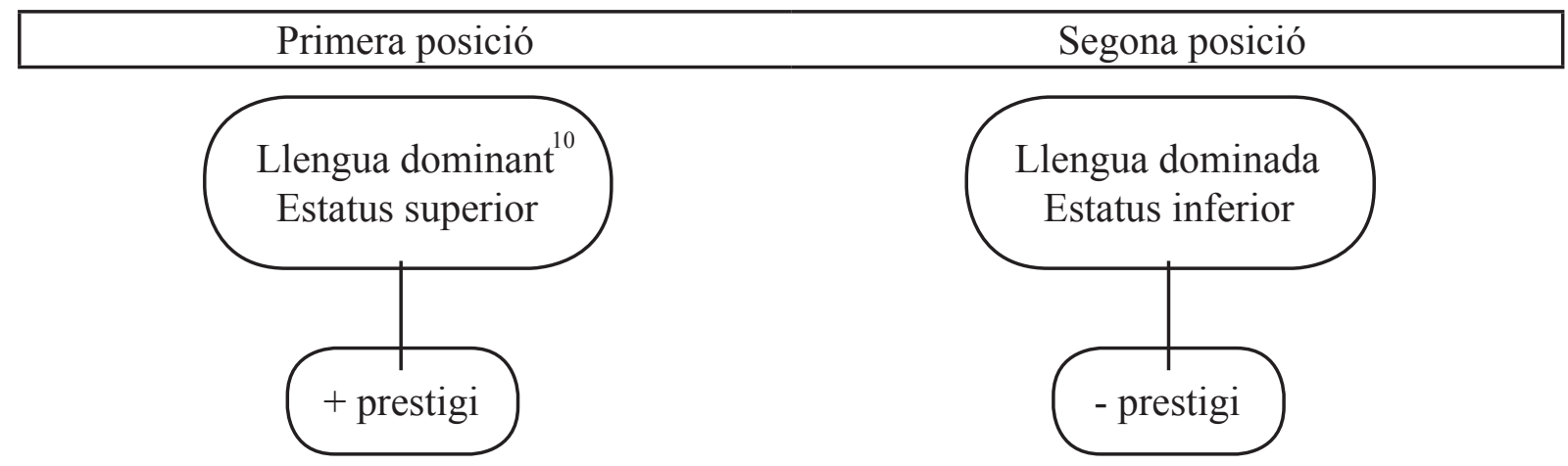

Figura 10. Relació del prestigi amb la jerarquia visual

En el nostre corpus hem observat l'aparició de signes institucionals en espais privats, aquests es troben als comerços i provenen de la Generalitat Valenciana (no de l'Ajuntament de València) i són aquells cartells que informen que un establiment disposa de fulls de reclamació, que no es pot fumar o que no es pot vendre alcohol a menors.

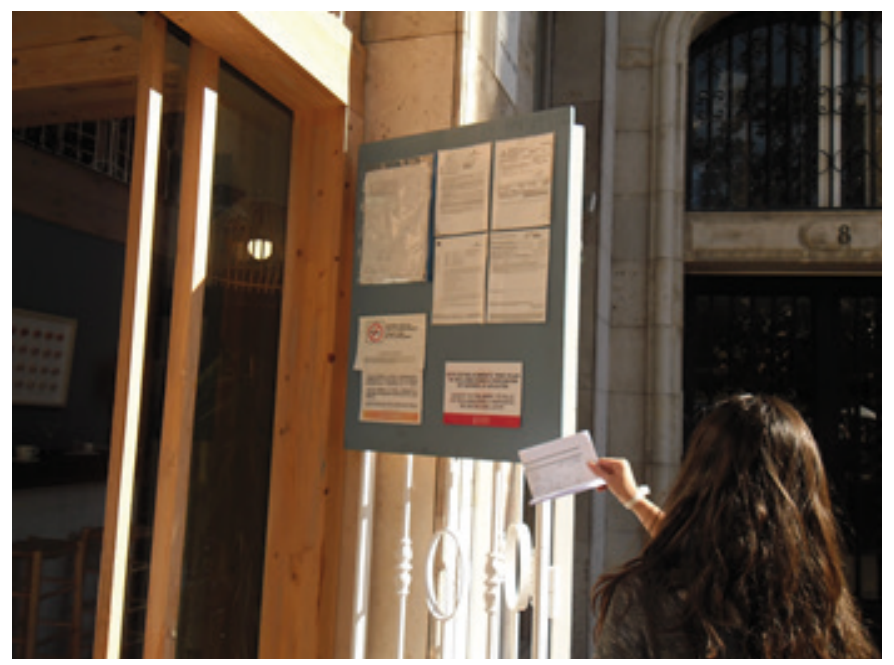

Figura 11. Signe bilingüe institucional en un espai privat

10 Regueira et al. (2013) fan referencia a la llengua en posició prominent com llengua dominant. 
Es tracta sempre de la mateixa classe de cartells, amb el mateix estil d'edició. Com veiem en la figura 11, apareixen les dues llengües oficials de la Comunitat Valenciana. Tanmateix, el fet que la primera llengua que aparega en el cartell siga el castellà (per tant és la llengua dominant) i que el català aparega en segona posició condueix a la visualització de la llengua pròpia dels valencians com a una llengua que té menys prestigi que el castellà, ja que ha sigut relegada a un estatus inferior.

Per altra banda, en la figura 12 el signe que apareix, que hem considerat institucional perquè ha estat emés pel Tribunal de les Aigües, és un exemple que el català cobra prestigi sobre el castellà i sobre l'anglés en institucions relacionades amb la cultura popular valenciana.

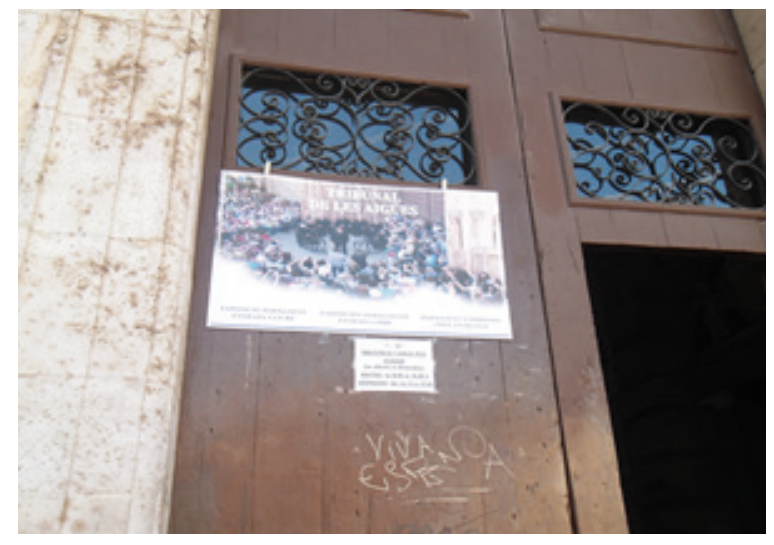

Figura 12. Signe institucional multilingüe

Un altre cas que hem trobat en el nostre corpus és el següent. En la figura 13, observem dos signes que pertanyen a una entitat financera ${ }^{11}$ que posa el català per damunt del castellà, per tant li està atorgant l'estatus de llengua dominant (més prestigi).

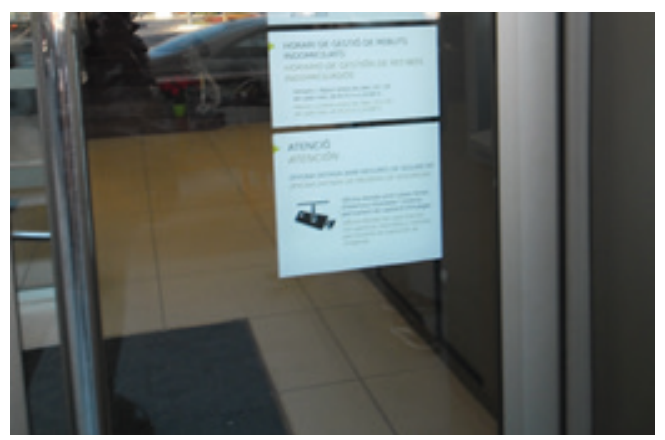

Figura 13. Signes privats bilingües

11 Aquesta entitat financera té seu a València, per tant no és d'estranyar que preferisca anteposar el català com a via de relació més afectiva amb els seus clients. 
En la figura 14 veiem que la situació és diferent, s'observa un conflicte, ja que el nom del carrer apareix escrit en castellà, mentre que «Registradors d'Espanya» està escrit en català:

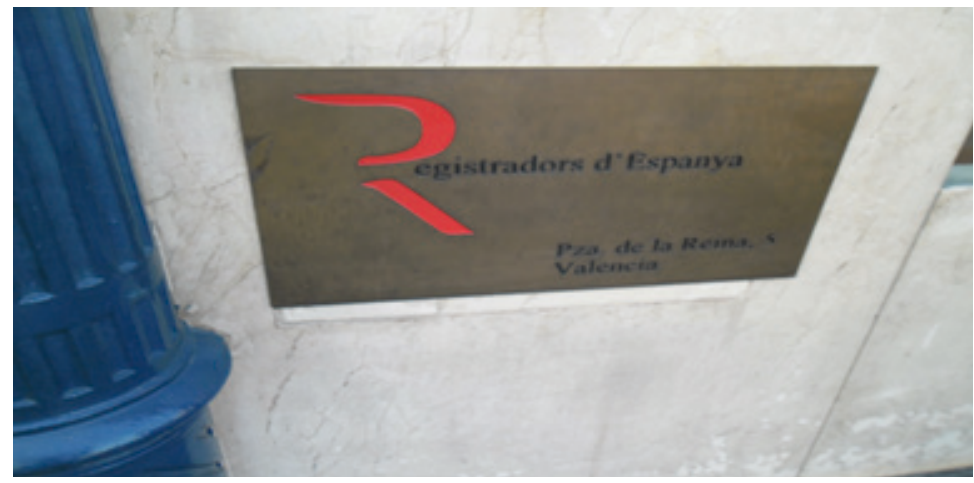

Figura 14. Signe privat bilingüe «conflictiu»

Es tracta d'un conflicte implícit amb relació als noms dels carrers. Una possible explicació pot ser que el costum dels valencians a nomenar els carrers en castellà complica el canvi de la denominació d'aquests al català segons la normativa de l'Ajuntament.

\subsubsection{Valor simbòlic del signes en català}

Landry i Bourhis (1997: 25) atorguen dos tipus de significat al signe: un és denotatiu, per tant té un valor informatiu, i l'altre és connotatiu, és a dir, conté un valor simbòlic. Relacionat amb aquest últim tipus de significat, hem trobat nombrosos exemples de signes amb valor simbòlic dins dels signes privats.

Es tracta d'un ús estratègic, ja que sobretot el català s'utilitza donant nom a empreses i establiments com els següents:
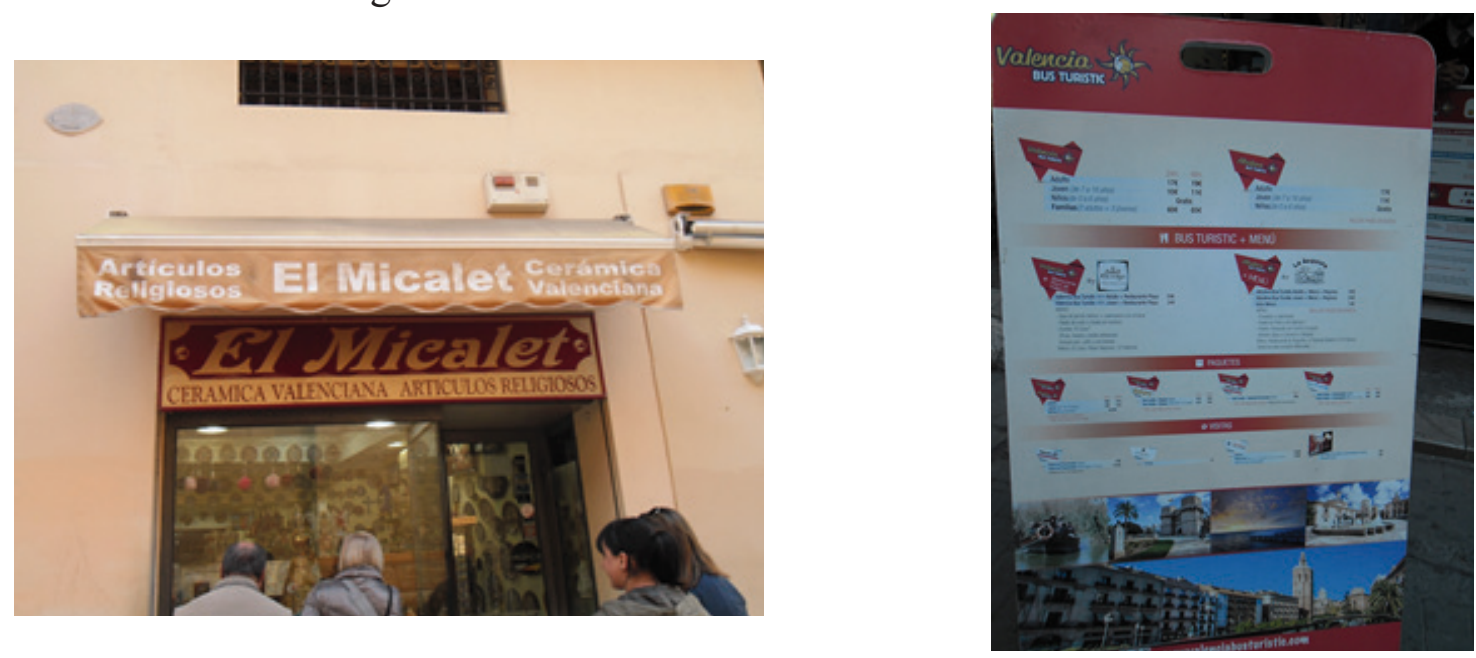

Figures 15 i 16. Signes amb valor simbòlic 
Tot i que el nom és en català (El Micalet i Valencia Bus Turístic), en aquests dos exemples la resta d'informació apareix en castellà. Per tant, la utilització de la llengua catalana té més relació amb el fet de crear una marca que es troba en connexió a la identitat de la ciutat. En el cas de la tenda El Micalet està clara aquesta connexió: es tracta d'una tenda ubicada al costat del Micalet (torre campanar de la catedral) i ven articles religiosos, per tant pren nom de la realitat, arquitectònica i religiosa, que envolta la tenda.

\section{Conclusions}

Després de l'anàlisi que hem realitzat, i d'acord amb els resultats obtinguts en aquesta investigació, podem comprovar si la hipòtesi de la qual partíem és correcta o no.

Hem comprovat que, efectivament, la llengua amb major representació als signes públics és el català. Tanmateix, ens ha sorprés que hi haja tan pocs signes multilingües en un espai on es concentren les visites de turistes estrangers. També hem pogut corroborar que les llengües predominants als signes privats són el castellà i l'anglés. L'aparició del català en aquest tipus de signes es redueix considerablement, mentre que l'anglés té una gran vitalitat en l'àmbit dels signes privats (tot i que el castellà s'usa en més ocasions). La utilització de l'anglés obeeix a la seua concepció com a llengua franca, és a dir, com un «vehículo común de comunicación» (Pons, 2012: 31). El procés de globalització que estem vivint fa possible que no es note com una cosa estranya la presència de la llengua anglesa en els signes del PL de València, tot i que no és una llengua oficial en el territori valencià, i és que «among the number of languages featured on signs, shop fronts, billboards and the like, English enjoys a privileged position when it comes to addressing a multilingual, heterogeneous readership» (Bruyèl-Olmedo i Juan-Garau, 2009: 1). Es podria pensar que els responsables dels comerços creuen que l'anglés serveix com llengua vehicular per a tots els visitants, per la qual cosa no resultaria necessari l'ús d'altres llengües.

Per tant, la política lingüística de l'Ajuntament de València i de la Generalitat Valenciana té un major compliment en els signes institucionals. Les excepcions que trobem són signes institucionals que pareixen antics, com pot ser el cas del signe de la figura 8 . Per altra banda, tot 
i que l'Ajuntament ofereix informació i assessorament, no són abundants els signes privats en català. Com hem assenyalat abans, el centre de València compta amb establiments turístics que busquen clients internacionals o nacionals i pareix que utilitzant la llengua castellana i l'anglés ja sufoquen les seues necessitats comunicatives. De fet, l'aparició en els símbols privats del català obeeix més a un ús simbòlic de la llengua que comunicatiu.

Finalment, l'estudi dels signes bilingües i multilingües on apareixia el català ens ha guiat a un estudi del prestigi d'aquesta llengua. De la nostra investigació podem concloure que el català en espais on competeix amb més llengües guanya més prestigi quan l'emissor dels signes es troba relacionat amb la cultura i identitat valenciana (cas del Tribunal de les Aigües) o quan pretén crear un vincle més afectiu amb els valencians (cas de l'entitat financera). 


\section{Bibliografia}

Ajuntament de València (2005). Reglament municipal sobre ús i normalització del valencià al municipi de València. [En línia] Disponible a: https://www.valencia.es/twav/ordenanzas. nsf/vCategoriasv/0678F746AFEAA382C12571A90040716B/\$file/R_us\%20valencia. pdf?openElement\&lang=2\&nivel=4 [Última consulta: 13/03/2018]

Backhaus, P. (2007). Linguistic Landscapes: A Comparative Study of Urban Multilingualism in Tokyo. Toronto: Clevedon/Buffalo/Multilingual Matters.

Ben-Rafael, E.; Shohamy, E.; Amara, M. H. i Trumper-Hecht, N. (2006). «Linguistic Landscape as Symbolic Construction of the Public Space: The Case of Israel», en International Journal of Multilingualism, Volum 3 (1), pp. 7-30. [En línia] Disponible a: https://doi. org/10.1080/14790710608668383 [Última consulta: 13/03/2018]

Bruyèl-Olmedo, A. i M. Juan-Garau (2009). «English as a lingua franca in the linguistic landscape of the multilingual resort of S'Arenal in Mallorca», en International Journal of Multilingualism, Volum 6 (4), pp. 386-411. [En línia] Disponible a: https://doi. org/10.1080/14790710903125010 [Última consulta: 13/03/2018]

Conselleria d'Educació i Ciència (1993). «Ordre d'1 de desembre de 1993, de la Conselleria d'Educació i Ciència, sobre l'ús de les llengües oficials en la toponímia, en la senyalització de les vies de comunicació I en la retolació dels serveis públics en l'àmbit territorial de la Comunitat Valenciana», en Diari Oficial de la Generalitat Valenciana, 15 de març de 1994 (2227). [En línia] Disponible a: http://www.dogv.gva. es/disposicio?sig=0594/1994\&url_lista= [Última consulta: 13/03/2018]

Generalitat Valenciana (1986). «Decret 145/1986, de 24 de novembre, del Consell de la Generalitat Valenciana, sobre senyalització de vies i serveis públics en l'àmbit territorial de la Comunitat Valenciana», en Diari Oficial de la Generalitat Valenciana, 20 de gener de 1987 (509). [En línia] Disponible a: http://www.dogv.gva.es/disposicio?sig=0070/1987\&url_ lista $=$ [Última consulta: 13/03/2018] 
Generalitat Valenciana (2017). «Decret 61/2017, de 12 de maig, del Consell, pel qual es regulen els usos institucionals i administratius de les llengües oficials en l'Administració de la Generalitat. [2017/4338]», en Diari Oficial de la Generalitat Valenciana, 23 de maig de 2017 (8046). [En línia] Disponible a: http:/www.dogv.gva.es/ disposicio?sig=004395/2017\&url_lista= [Última consulta: 13/03/2018]

Hernández-Campoy, J.M. (2004). «El fenómeno de las actitudes y su medición en sociolingüística», en Tonos digital, Volum 8, pp. 29-56. [En línia] Disponible a: http://www.um.es/ tonosdigital/znum8/portada/monotonos/04-JMCAMPOYa.pdf [Última consulta: $13 / 03 / 2018]$

Landry, R. i Bourhis, R. (1997). «Linguistic Landscape and Ethnolinguistic Vitality. An Empirical Study», en Journal of language and social psychology, Volum 16 (1), pp. 23-49. [En línea] Disponible a: https://doi.org/10.1177/0261927X970161002 [Última consulta: $13 / 03 / 2018]$

Pons, L. (2012). El paisaje lingüístico de Sevilla. Lenguas y variedades en el escenario urbano hispalense. Sevilla: Diputación de Sevilla.

Regueira, X. L.; López Docampo, M. i Wellings, M. (2013). «El paisaje lingüístico en Galicia», en RILI, Volum 11, Número 1, pp. 39-62. 